\title{
Effects of Valsartan vs Amlodipin on renal function in salt loaded spontaneously hypertensive rats
}

\author{
Kalina Gjorgjievska $^{{ }^{*}}$, Dimce Zafirov ${ }^{1}$, Maja Jurhar Pavlova ${ }^{2}$, Svetlana Cekovska ${ }^{3}$ \\ ${ }^{1}$ Institute of Preclinical and Clinical Pharmacology with Toxicology, Medical Faculty, Skopje \\ ${ }^{2}$ Institute of Microbiology and Parasitology, Medical Faculty, Skopje \\ ${ }^{3}$ Institute of Medical and Experimental Biochemistry, Medical Faculty, Skopje
}

Received: April 2014; Accepted: June 2014

\begin{abstract}
The goal of this study was to compare the effects of valsartan and amlodipin on the systolic blood pressure and parameters specific to the renal function in salt loaded spontaneously hypertensive rats (SHR). 32 male SHR were used at age of 20 weeks and body weight ranging between 265-300 g. From 8 weeks of age tab water was replaced with a solution of $\mathrm{NaCl}(1 \%)$ given ad libitum. Rats were divided into 2 groups: valsartan treated group SHRVAL $(\mathrm{n}=16)$ in which valsartan was given at a dose of $10 \mathrm{mg} / \mathrm{kg}$ b. w. and amlodipine treated group SHRAMLO $(\mathrm{n}=16)$ in which amlodipine was given at a dose of $5 \mathrm{mg} / \mathrm{kg} \mathrm{b}$. w. For a period of 12 weeks we have evaluated the effect of the investigated drugs on systolic blood pressure, body weight and renal function tests. In salt loaded rats amlodipine was more effective in reducing the systolic blood pressure in contrast to valsartan who had more pronounced effect on renal parameters most evident in proteinuria. Since both treatment groups have different mechanism of action a combination therapy may be beneficial in improving renal function in SHR rats.
\end{abstract}

Key words: Salt loading, SHR rats, renal function, valsartan, amlodipin.

\section{Introduction}

In patients with kidney disease antihypertensive drugs are given in order to reverse the pathological processes in the kidneys and to prevent the development of nephrosclerosis. Pharmacological inhibition of the renninangiotensin-aldosteron system (RAAS) with angiotensin -converting enzyme inhibitors (ACEi) and angiotensin receptor blockers (ARB) has attenuated the decline of renal function associated with diabetic (Lewis et al., 1993; Parving et al., 2004; Ravera et al., 2007; Ravid et al., 1993)

\footnotetext{
*kmilosevska@yahoo.com
}

and non-diabetic (GISEN study group, 1997; Kunz et al., 2008) forms of chronic renal disease (CRD) and as such became a standard in preserving renal function in patients with CRD. Whether the protective effects on the kidney function can be restricted only to the RAAS inhibitors or this effect can be extended to other forms of therapy such as calcium channel blockers (CCB) is not clearly defined. CCBs are heterogeneous class of drugs used in treatment of coronary heath disease and hypertension. Amlodipine, a third-generation dihydropyridine $\mathrm{CCB}$ is characterized with high vascular selectivity and relatively low negative inotropic effects. In animal experimental studies amlodipine was able to prevent the development of hypertension-related left ventricular hypertrophy and 
dysfunction (Tomassoni et al., 2003; Watanabe et al., 1998). Controversy exists regarding the effects of CCB on progressive renal injury since both positive (Bezerra et al., 2005; Kanno et al., 1994) and negative (Dworkin et al., 1996) results have been published.

The goal of this study was to compare the effects of valsartan and amlodipin on the systolic blood pressure and parameters specific to the renal function in salt loaded spontaneously hypertensive rats (SHR) rats.

\section{Materials and methods}

In this study 32 male SHR rats were used. These animals were 5 generation of rats originating from Charles River Laboratories Inc. breaded at the animalia of the Institute of Preclinical and Clinical Pharmacology and Toxicology, Med. Fac. SK.

In order to minimize the effects of the inter-individual differences, all animals were at age of 20 weeks and body weight ranging between 265-300 g. Rats were fed with standard rats chow and housed in cages in groups of 5-6 in a temperature controlled environment $\left(\sim 22{ }^{\circ} \mathrm{C}\right)$ and 12-h light/dark cycle. From age of 8 weeks tab water was replaced with a solution of $\mathrm{NaCl}(1 \%)$ given ad libitum. The experimental protocol met the national guidelines on proper care and use of animals in laboratory research.

SHR rats were divided into 2 groups: valsartan treated group SHRVAL $(n=16)$ in which valsartan was given at a dose of $10 \mathrm{mg} / \mathrm{kg} \mathrm{b}$. w. and amlodipine treated group SHRAMLO $(n=16)$ in which amlodipine was given at a dose of $5 \mathrm{mg} / \mathrm{kg} \mathrm{b}$. w. Drugs were given daily, for a period of 12 weeks, in the morning, by gavage.
During the treatment period we have evaluated the effect of the investigated drugs on systolic blood pressure (SBP), body weight and renal function tests. SBP was measured by a pletismografic method (IITC Life Science MRBP Blood Pressure System, California, USA) on the rats tail in 4-week intervals. Body weight was measured every second week of treatment. Renal functional tests were performed in 4-week intervals after urine was collected in metabolic cages in 24 hour intervals for determination of the following parameters: diuresis (24 hour urine), $\mathrm{pH}$ analysis, proteinuria and urine creatinine. Urine $\mathrm{pH}$ was measured by using test strips (Combina $10 \mathrm{M}$, Human $\mathrm{GmbH}$, Germany), urine protein in 24-hour urine samples were determined turbidimetrically (Biochemical analysator ChemWell Awareness Technology) with sulfosalyc acid (Meulemans, 1961).

Creatinine clearance was used as a specific sensitive marker for detection of altered renal function of the animals. In order to determine the serum levels of creatinine, blood was taken by venepuncture from the orbital sinus of the rats. Blood samples of $400 \mu \mathrm{l}$ were taken for serum separation $(200 \mu \mathrm{l})$. Serum and urine creatinine were determined fotometrically (Bartels and Bohmer, 1972). Creatinine clearance $(\mathrm{CrCl})$ was calculated from the creatinine concentration in the collected urine sample, urine flow rate and the plasma concentration of creatinine as $\mathrm{ClCr}($ total $)=$ eliminated $\mathrm{Cr}$ in urine $(\mathrm{mg} / \mathrm{min}) / \mathrm{Cr}$ concentration in serum $(\mathrm{mg} / \mathrm{ml})$ and $\mathrm{ClCr} / 100 \mathrm{~g} \mathrm{~b} . \mathrm{w} .=\mathrm{ClCr}$ (total) $\times 100 /$ b.w.

Statistical analysis: Data were expressed as mean \pm SD. Student's unpaired and paired $t$ - test and one way analysis of variance ANOVA were used as appropriate. $\mathrm{P}$ values $<0.05$ were considered as statistically significant.

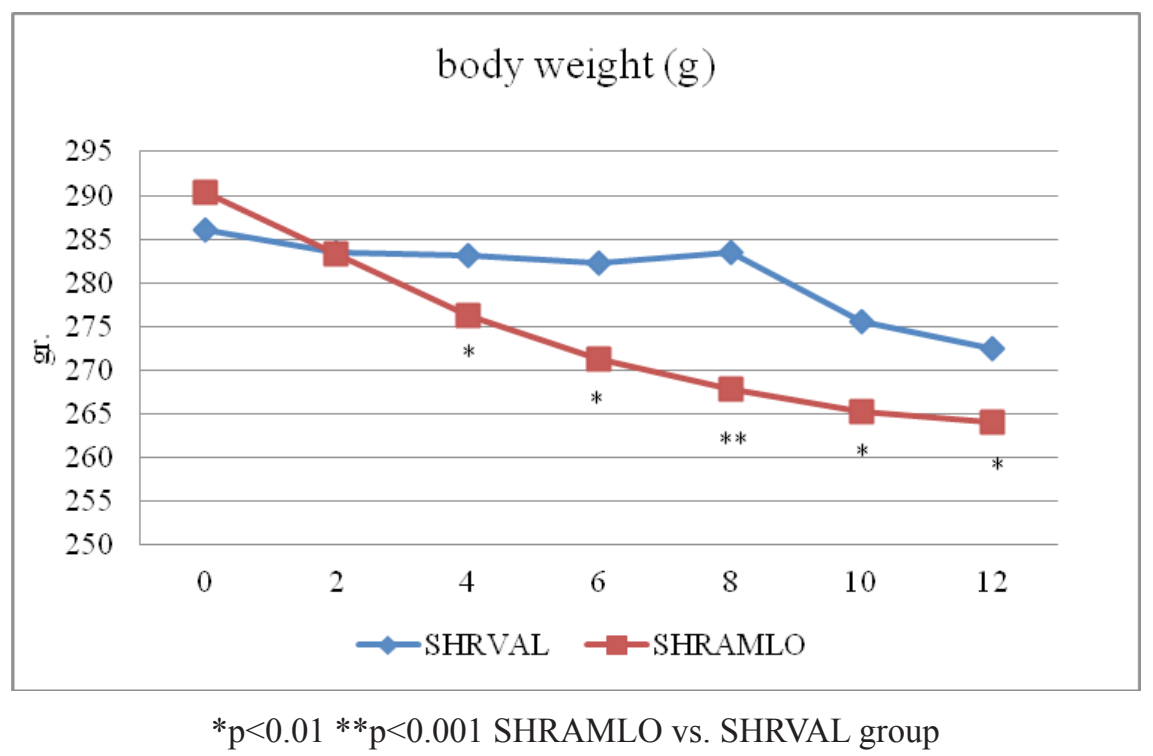

Fig. 1. Effects of valsartan and amlodipine on body weight in salt loaded SHR rats for a investigative period of 12 weeks. 


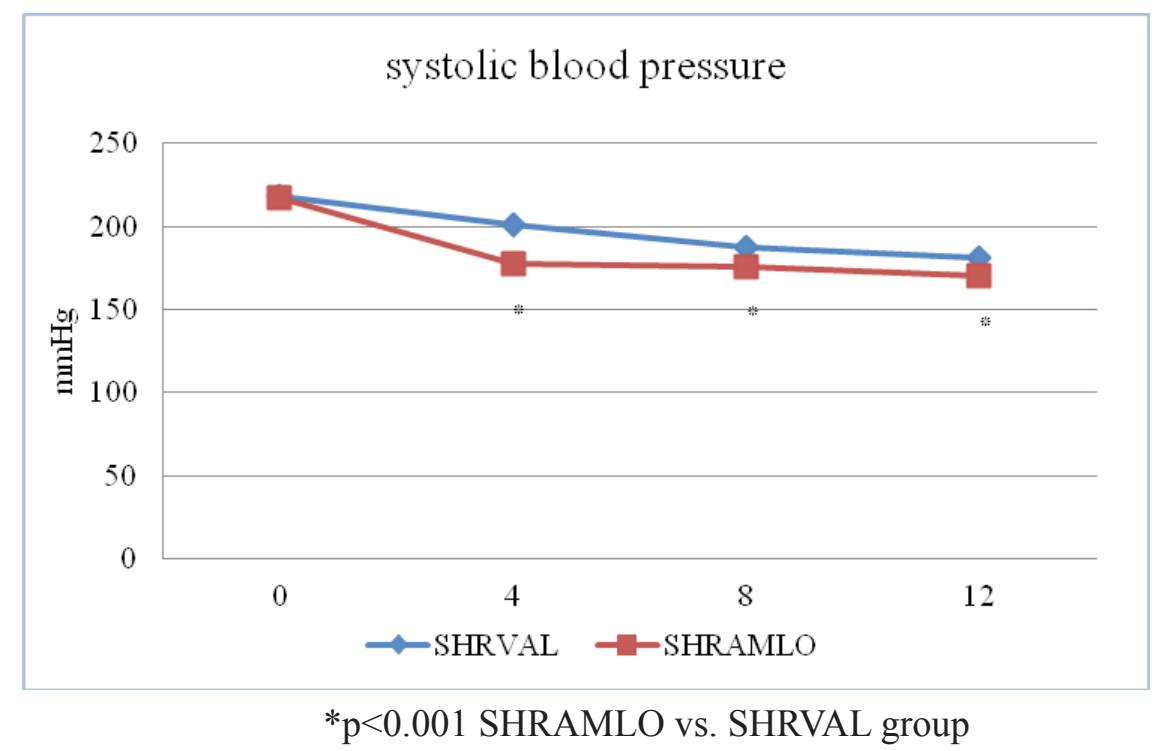

Fig. 2. Effects of valsartan and amlodipine on SBP in salt loaded SHR rats for a investigative period of 12 weeks.

\section{Results}

Body weight: For the investigative period a gradual decrease of body weight was noticed in both groups. The decrease of body weight in the SHRVAL group of rats was less pronounced and by week 12 was $4.47 \%$ compared to baseline values. Decrease of body weight in the SHRAMLO group by the end of treatment period compared to baseline values was $9.04 \%$ (Fig. 1).

Systolic blood pressure: A gradual decrease of systolic blood pressure was noticed in the SHRVAL group. Decrease was more pronounced by week $8(14.1 \%)$ and week 12
$(17 \%)$ of the study. Amlodipine in SHR salt loaded rats had greater effect on SBP than valsartan with a decrease or $18.3 \%$ by week 4 , followed by $19.3 \%$ for week 8 and $21.7 \%$ decrease by week 12 . For the period of 4-12 weeks decrease of SBP with amlodipine compared to valsartan was statistically more significant $(\mathrm{p}<0.001)$ (Fig. 2).

Serum Creatinine: A gradual increase of serum creatinine was noticed in both treated groups. Increase was less pronounced in the SHRVAL group - 19\% by week 8 and $26.5 \%$ by week 12 . In the SHRAMLO group increase was $21.1 \%$ by week 8 and $35.3 \%$ by week 12 . Compared to the SHRAMLO group in the SHRVAL group a significant

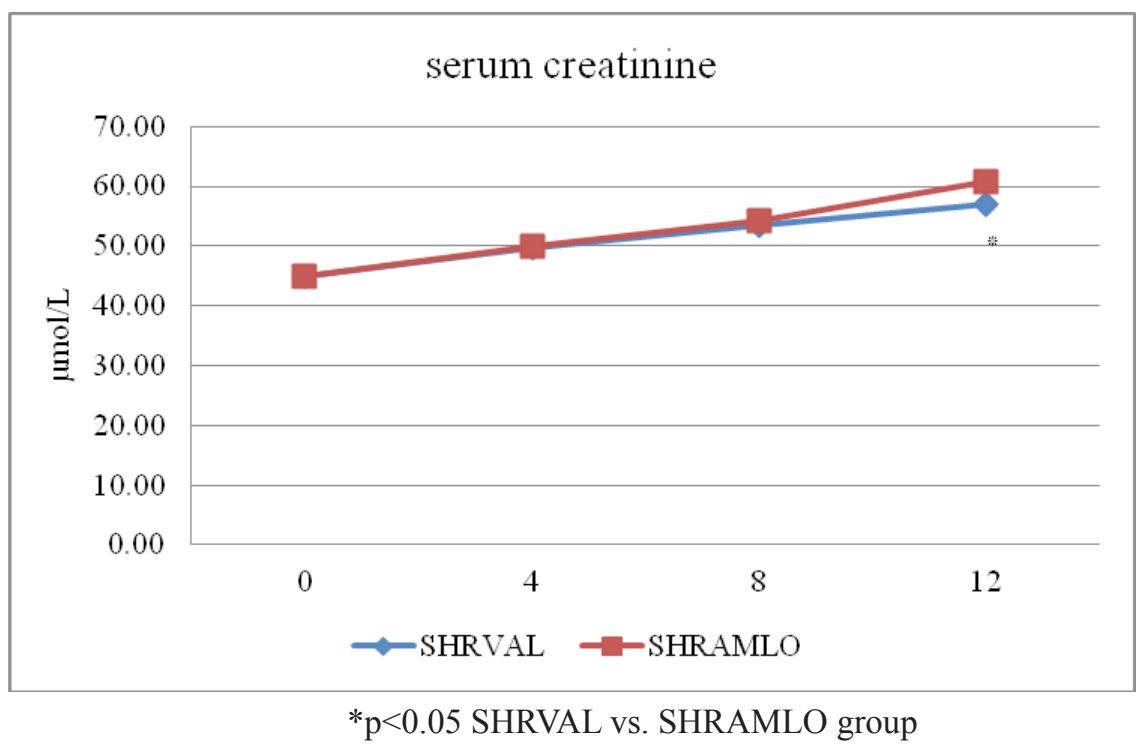

Fig. 3. Effects of valsartan and amlodipine on serum creatinine in salt loaded SHR rats for a investigative period of 12 weeks. 


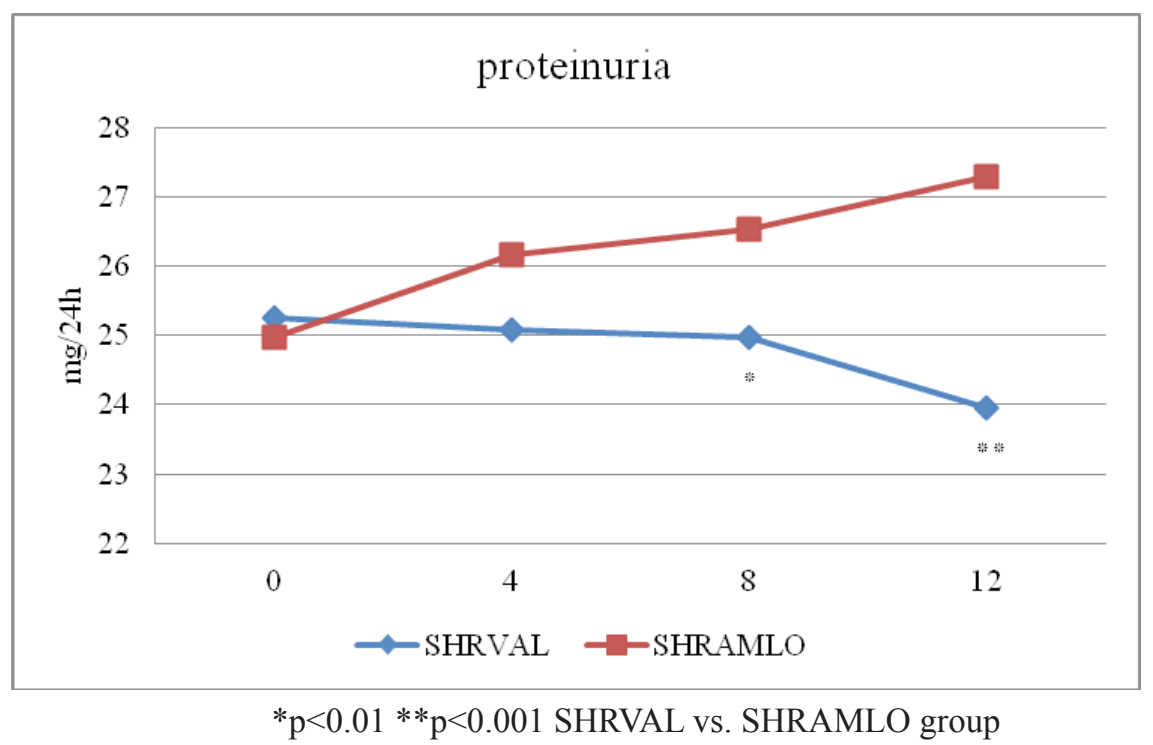

Fig. 4. Effects of valsartan and amlodipine on proteinuria in salt loaded SHR rats for a investigative period of 12 weeks.

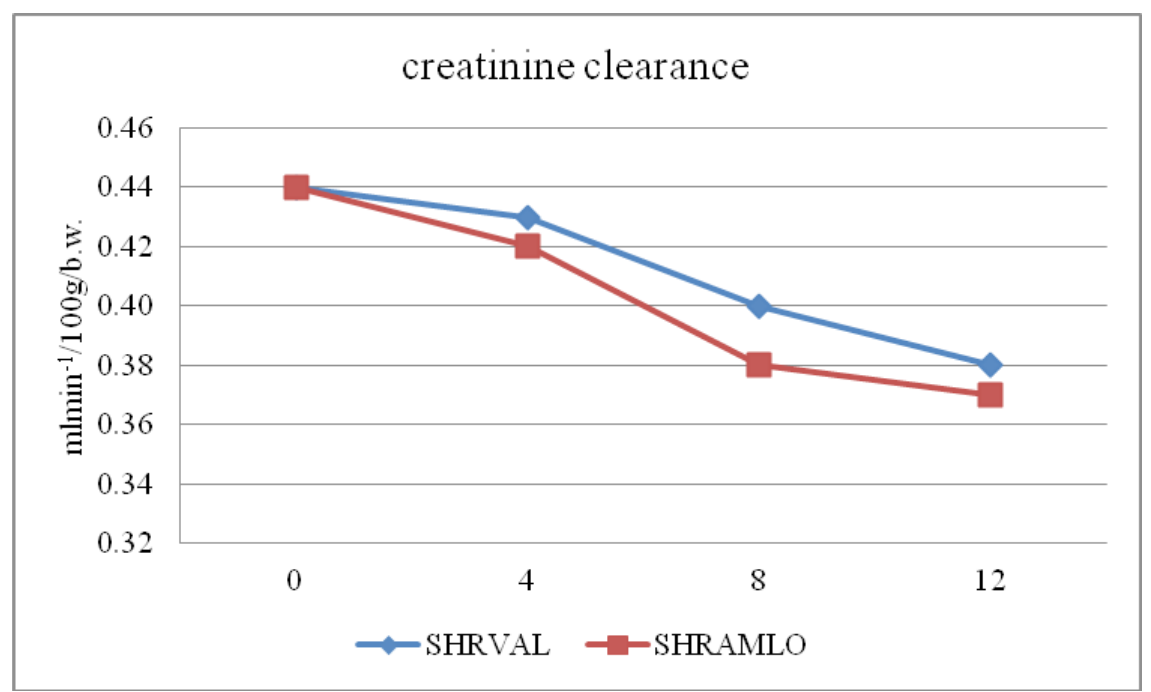

Fig. 5. Effects of valsartan and amlodipine on creatinine clearance in salt loaded SHR rats for a investigative period of 12 weeks.

difference in the serum creatinine values was noticed only for the point of 12 weeks of treatment ( $<<0.05)$ (Fig. 3).

Diuresis: In both treated groups a decrease of diuresis compared to baseline levels was noticed. Decrease in diuresis was more pronounced in SHRVAL group with a $31 \%$ decrease by week 8 and $39 \%$ decrease by week 12 . In SHRAMLO group decrease in diuresis was $30 \%$ by week 8 and $39 \%$ by week 12 . For the period of $4-12$ weeks the decrease of diuresis with valsartan compared to amlodipine was statistically insignificant.

Urine $p H$ : Between the two investigated groups of animals there was no significant difference in urine $\mathrm{pH}$.

Proteinuria: In the SHRAMLO group a significant $(p<0.001)$ increase of the proteinuria compared to baseline values was noticed. Proteinuria was increased to $4.7 \%$ for week $4,6.2 \%$ by week 8 and $9.24 \%$ for week 12 . In the SHRVAL group gradual decrease in proteinuria was noticed mostly evident by week 12 (5\%) (Fig. 4).

Creatinine clearance: Creatinine clearance was used as specific parameter to assess GFR. In both treatment groups creatinine clearance gradually decreased with more evident effects at the end of treatment. Between the two investigated groups during the course of the study no significant difference in creatinine clearance was noted (Fig. 5). 


\section{Discussion}

In this study we have decided to additionally aggravate hypertension and tissue damage by "salt loading" SHR rats with $1 \%$ solution of $\mathrm{NaCl}$ ( used as a drinking solution instead of tab water) from age of 8 to 20 weeks of age. SHR are often used animal model of human essential hypertension (Trippodo and Frohlich, 1981). SHR rats are considered to be a salt-sensitive animal model (Katori and Maima, 2006; Susic et al., 2009). In this animal model additional salt loading increases arterial pressure and also to contributes to the damages to the hypertension target organs (heart, arteries, kidneys) structurally and functionally trough pressure-independent mechanisms (Cavanagh et al., 2010; Limas et al., 1980; Matavelli et al., 2007; Varagic et al., 2006).

For the investigative period a gradual decrease of body weight was noticed in both groups. The decrease of body weight in the SHRVAL group of rats was less pronounced. SHR rats given salt overload usually have lower body weight compared to animals that are not salt loaded (Susic et al., 2010; Varagic et al., 2006) presumably due to structural and functional cardiovascular and renal injury (Matavelli et al., 2007; Susic et al., 2010).

In the present study amlodipine has shown to be more effective in reducing the SBP in SHR rats. Pronounced hypotensive effect of amlodipine in comparison to valsartan was evident through the complete course of the study. In regards to the renal functional tests both amlodipine and valsartan were effective in increasing serum creatinine levels. Significant difference in serum creatinine values in valsartan treated animals in comparison to amlodipine were shown at the end of treatment (12 week point). Both investigated groups showed no significant difference in creatinine clearance. The results of the present study confirm previous reports on effectives of amlodipine in reducing SBP in SHR rats. When comparing the effects of valsartan and amlodipine (Dong et al., 2011) in salt loaded SHRSP rats, amlodipine was more effective in reducing blood pressure. In partly nephrectomized SHR rats (Kanno et al., 1994) amlodipine was able to reduce SBP and also to suppress urinary protein excression. When given to SHRSP rats amlodipine in a dose dependent manner reduced SBP (Kyselovic et al., 2001) and inhibited paradoxical increases in plasma rennin activity and rennin mRNA in kidneys. In nephrectomised salt-loaded SHR rats amlodipine attenuated increases in SBP, urinary protein excretion and serum creatinine concentration with effects comparable to enalapril (Saruta et al., 1995). In this study proteinuria was decreased only in the valsartan treated group.

Although the extent of sustained damage on the kidneys during hypertension is expected to be proportional to the degree of the blood pressure exposure, the severity of renal damage is not determinated by the systemic BP but to the degree to which the pressure is transmitted to the renal microvasculature evident in the increase of the glomerular pressure. The increase of the glomerular pressure is ascribed to the greater dilatation of the afferent as compared to the efferent arteriole. This relative efferent arteriolar vasoconstriction is attributed to the tonic vasoconstrictor effects of Angiotensin II (Ang II). Therefore it is believed that Ang II plays a major role in the pathogenesis of glomerular hypertension and can be intrinsic to the glomerular hemodynamic maladaptation (Griffin and Bidani, 2006). The effects of increased or disregulated growth factor expression associated with glomerular hypertrophy are also of great importance. Increase in locally generated Ang II triggers multiple downstream pathways that lead to proteinuria and increased expressions and/or activity of profibrotic mediators such as TGF- $\beta$ and plasminogen activator inhibitor-1 (Fogo and Ichikawa, 1990; Ketteler et al., 1995; Wolf and Neilson, 1993).

The mechanism responsible for valsartan effectiveness in ameliorating renal function may be due to the attenuation of both circulating and local rennin-angiotensin system (Long et al., 2004). It seems that the decrease of SBP achieved with amlodipin was not as important factor in preserving renal function since proteinuria was only decreased in valsartan treated animals. The precise mechanism by which amlodipine can reverse the functional renal abnormalities in the essential hypertensive state, and by which they may attenuate the progression of hypertensive renal disease, are unknown. The net effect of calcium antagonists on glomerular hemodinamics is determent by the balance between the reduction in afferent arteriolar resistance and the fall in systemic blood pressure (Robles, 2004). Amlodipine also increases endothelial nitric oxide (NO) bioavailability, firstly via enhanced NO formation, and secondly by prolonging the half-life of NO through antioxidative properties, and suppressing proinflammatory cytokines and free radical generation (Bauer and Reams, 1989; Berkels et al., 2004), mediated in part by the prostanoid endothelium-derived factors (Chou et al., 2002). The calcium antagonism seems to play a role in the regulation of apoptosis and proliferation of glomerular cells and may be effective in preventing nephrosclerosis exacerbated by $\mathrm{NO}$ synthesis inhibition (Watanabe et al., 2000).

\section{Conclusion}

In salt loaded rats amlodipine was more effective in reducing the SBP, but the effects on renal parameters mostly proteinuria were more evident in the group of animals treated with valsartan. Since both treatment groups have different mechanism of action a combination therapy may be beneficial in improving renal function in SHR rats. 


\section{References}

Bartels, H., Bohmer, M.,1972. Serum creatinine determination without protein precipitation. Clin. Chim. Acta. 37, 193-197.

Bauer, J.H., Reams, G.P., 1989. Renal protection with calcium antagonism in essential hypertension. Clin. Invest. Med.12, 300-304.

Berkels, R., Taubert, D., Bartels, H., Breitenbach, T., Klaus, W., Roesen, R., 2004. Amlodipine increases endothelial nitric oxide by dual mechanisms. Pharmacol. 4 (70), 39-45.

Bezerra, D.G., Pires, K.M.P., Mandarim-de-Lacerda, C.A., 2005. Amlodipine preserves the glomerular number in spontaneously hypertensive rats. J. Cel. Mol. Med. 9 (4), 966-971.

Cavanagh, E.M., Ferder, L.F., Ferder, M.D., Stella, I.Y., Toblli, J.E., Inserra, F., 2010. Vascular structure and oxidative stress in salt-loaded spontaneously hypertensive rats: effects of losartan and atenolol. Am. J. Hypertens. 23(12), 1318-1325.

Chou, T.C., Yang, S.P., Pei, D., 2002. Amlodipine inhibits proinflammatory cytokines and free radical production and inducible nitric oxide synthase expression in lipopolysaccharide/interferon- $\gamma$-stimulated cultured vascular smooth muscle cells. Jpn. J. Pharmacol. 89, 157-163.

Dong, Y.F., Kataoka, K., Tokutomi, Y., Nako, H., Nakamura, T., Toyama, K., Sueta, D., Koibuchi, N., Yamamoto, E., Ogawa, H., Kim-Mitsuyama, S., 2011. Beneficial effects of combination of valsartan and amlodipine on salt-induced brain injury in hypertensive rats. J. Pharmacol. Exp. Ther. 339(2), 358-366.

Dworkin, L.D., Tolbert, E., Recht, P.A., Hersch, J.C., Feiner, H., Levin, R.I., 1996. Effects of amlodipine on glomerular filtration, growth, and injury in experimental hypertension. Hypertension. 27, 245-250.

Fogo, A., Ichikawa, I., 1990. Evidence of central role of glomerular growth promoters in the development of sclerosis. Semin. Nephrol. 14(9), 329-342.

Griffin, K.A., Bidani, A.K., 2006. Progression in renal disease: renoprotective specificity of rennin-angiotensin system blockade. Clin. J. Am. Soc. Nephol. 1, 1054-1065.

Gruppo Italiano di studi epidemiologici in nefrologia (GISEN), 1997. Randomised placebo-controlled trial of effect of ramipril on decline in glomerular filtration rate and risk of terminal renal failure in proteinuric, non-diabetic nephropathy. Lancet. 349, 1857-1863.

Kanno, Y., Suzuki, H., Okada, H., Saruta, T., 1994. Renal protective effects of amlodipine on partially nephrectomized spontaneously hypertensive rats fed a high-salt diet. J. Cardiovasc. Pharmacol. 23, 480-484.

Katori, M., Majima, M., 2006. A missing link between a high salt intake and blood pressure increase. J. Pharmacol. Sci. 100, $370-390$.

Ketteler, M., Noble, N.A., Border, W.A., 1995. Transforming growth factor-beta and angiotensin II: The missing link from glomerular hyperfiltration to glomerulosclerosis? Ann. Rev. Physiol. 57, 279 -295.

Kunz, R., Friedrich, C., Wolbers, M., Mann, J.F., 2008. Metaanalysis: effect of monotherapy and combination therapy with inhibitors of the renin angiotensin system on proteinuria in renal disease. Ann. Intern. Med. 148 (1), 30.

Kyselovic, J., Krenek, P., Wibo, M., Godfraind, T., 2001. Effects of amlodipine and lacidipine on cardiac remodelling and renin production in salt-loaded stroke-prone hypertensive rats. Br. J. Pharmacol. 134 (7), 1516-1522.
Lewis, E.J., Hunsicker, L.G., Bain, R.P., Rohde, R.D., 1993. The effect of angiotensin-converting enzyme inhibition on diabetic nephropathy. N. Engl. J. Med. 329, 1456-1462.

Limas, C., Westrum, B., Limas, C.J., Cohn, J.N., 1980. Effect of Salt on Vascular Lesions of Spontaneously Hypertensive Rats. Hypertension. 2, 477-489.

Long, D.A., Price, K.L., Herrera-Acosta, J., Johnson, R.J., 2004. How does angiotensin II cause renal injury? Hypertension. 43, 722-723.

Matavelli, L.C., Zhou, X., Varagic, J., Susic, D., Frohlich, E.D., 2007. High-salt diet produces severe renal dysfunction independently of changes in arterial pressure in spontaneously hypertensive rats (SHR). Am. J. Physiol. Heart. Circ. Physiol. 292(H), 814-819.

Meulemans, D., 1961. Determination of total protein in spinal fluid with sulphosalycilic acid and trichloroacetate. Clin. Chim. Acta. 5, 757-761.

Parving, H.H., Andersen, S., Jacobsen, P., Christensen, P.K., Rossing, K., Hovind, P., Rossing, P., Tarnow, L., 2004. Angiotensin receptor blockers in diabetic nephropathy: renal and cardiovascular end points. Semin. Nephrol. 24 (2), 147157.

Ravera, M., Re, M., Deferrari, G., 2007. Risk and prevention of diabetic nephropathy. G. Ital. Nefrol. 24 (38), 13-19.

Ravid, M., Savin, H., Jutrin, I., Bental, T., Katz, B., Lishner, M., 1993. Long-term stabilizing effect of angiotensin-converting enzyme inhibition on plasma creatinine and on proteinuria in normotensive type II diabetic patients. Ann. Intern. Med.118,577-581.

Robles, R., 2004. Calcium antagonists and renal failure: new properties for new generations. Med. Hypotheses. Res. 3, 709-725.

Saruta, T., Kanno, Y., Hayashi, K., Suzuki, H., 1995. Renal effects of amlodipine. J. Hum. Hypertens. 9 (1), 11-16.

Susic, D., Fares, H., Frohlich, E.D., 2009. Salt, Arterial pressure and cardiovascular and renal damage. Ochsner. J. 9, 197203.

Susic, D., Varagic, J., Frohlich, E.D., 2010. Cardiovascular effects of inhibition of rennin-angiotensin-aldosterone system components in hypertensive rats given salt excess. Am. J. Physiol. Heart. Circ. Physiol. 298 (H), 1177-1181.

Tomassoni, D., Sabbatini, M., Amenta, F., 2003. Effect of different dihydropyridine-type $\mathrm{Ca} 2+$ antagonists on left ventricle hypertrophy and coronary changes in spontaneously hypertensive rats. J. Cardiovasc. Pharmacol. 41, 544-552.

Trippodo, N.C, Frohlich, E.D., 1981. Similarities of genetic (spontaneous) hypertension. Man and rat. Circ. Res. 48, 309319.

Varagic, J., Frohlich, E.D., Diez, J., Susic, D., Ahn, J., Gonsales, A., Lopez, B., 2006. Myocardial fibrosis, impared coronary hemodynamics and biventricular dysfunction in salt-loaded SHR. Am. J. Physiol. Heart. Cir. Physiol. 290, 1503-1509.

Watanabe, M., Kawaguchi, H., Onozuka, H., et al. 1998. Chronic effects of enalaprile and amlodipine on cardiac remodeling in cardiomyopathic hamster hearts. J. Cardiovasc. Pharmacol. 32, 248-259.

Watanabe, S., Ono H., Ishimitsu, T., Matsuoka, H., Ono, Y., Fujimori, T., 2000. Calcium antagonist inhibits glomerular cell apoptosis and injuries of L-NAME exacerbated nephrosclerosis in SHR. Hypertens. Res. 23, 683-691.

Wolf, G., Neilson, E.G., 1993. Angiotensin II as a renal growth factor. J. Am. Soc. Nephrol. 3, 1531-1540. 


\title{
Резиме
}

\section{Ефекти на Васартан и Амлодипин врз реналната функција кај спонтано хипертензивни стаорци оптеретени со сол}

\author{
Калина Ѓ Грѓиевска ${ }^{1 *}$, Димче Зафиров ${ }^{1}$, Маја Јурхар Павлова $^{2}$, Светлана Цековска ${ }^{3}$

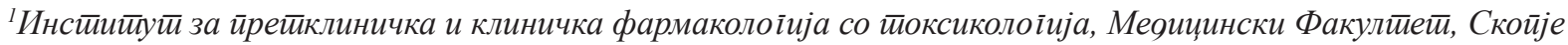 \\ ${ }^{2}$ Инстиийуй за микробиолоіија со йаразитолоіија, Меоицински Факулиетеи, Скойје

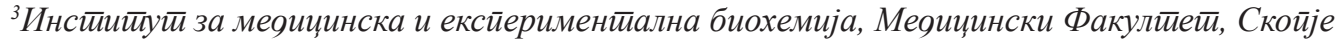

Клучни зборови: оптеретување со сол, бубрежна функција, СХР стаорци, валсартан, амлодипин.

Целта на оваа студија е да се компарираат ефектите на васлартан и амлодипин врз систолниот крвен притисок и параметрите специфични за реналната функција кај спонтано хипертензивни (СХР) стаорци оптеретени со сол. Во оваа студија беа употребени 32 СХР стаорци на возраст од 20 недели и телесна тежина од 265-300 гр. Кај стаорците на возраст од 8 недели водата беше заменета со 1\% раствор на $\mathrm{NaCl}$ даден ad libitum. Стаорците беа поделени во две групи: валсартан третирана група SHRVAL (n=16) во доза од $10 \mathrm{mg} / \mathrm{kg}$ т.т и амлодипин третирана група на стаорци SHRAMLO (n=16) даден во доза од $5 \mathrm{mg} / \mathrm{kg}$ т.т. Во период од 12 недели беше одредуван ефектот на испитуваните лекови врз систолниот крвен притисок, телесната тежина и параметри специфични за бубрежната функција.

Кај стаорци оптеретени со сол амлодипин се покажа како поефикасен во редукцијата на крвниот притисок за разлика од валсартан кој покажа поизразени ефекти врз реналните параметри највидливи во намалувањето на протеинуријата. Бидејќ двата лека делуваат преку различен механизам на дејство, дадени во комбинација би имале поизразен ефект врз реналната функција кај СХР стаорци. 